\title{
Developing personnel's new professional competencies in the context of the digital economy
}

\author{
Evgeny Shcherbik ${ }^{1},{ }^{*}$ Tatyana Patrakhina ${ }^{1}$, Aset Tagirova ${ }^{1}$, Tatyana Galynchik ${ }^{1}$ \\ ${ }^{l}$ Nizhnevartovsk State University, Nizhnevartovsk, Russia \\ "Email:zemaid@rambler.ru
}

\begin{abstract}
Digital transformation is becoming more and more relevant globally. There has been a comprehensive study on various aspects of the digital economy and its impact on the socio-economic sphere. This sphere is also emphasised as a priority at the local level, taking into account regions' disproportionate development. The world economy is becoming increasingly digital and technological, and economic relations are becoming more complex, the virtualisation of the economy intensifies. The analysis of the socio-economic conditions for the development and implementation of the digital competencies model and a comprehensive assessment of the opportunities and the current digital economy status of the country and the region reveals that at the time, Russia is not in the lead. Still, among all its territories, Khanty-Mansi Autonomous Area-Yugra is top-placed in the rankings. The current Russian economy is featured by its transition to an innovative management system and information society, which accelerates the digitisation of life, communication media and technologies. This article is devoted to developing personnel's professional competencies, the factors affecting competitive advantages, and the successful development of both businesses and the area they grow in. The developed model is suggested to be used according to the needs and goals of a particular organisation both as it is and supplementing it with other elements, adjusting it to the conditions of the object.
\end{abstract}

Keywords: Digital economy, Professional competencies, Regional competency model, Digital competencies.

\section{INTRODUCTION}

In the current conditions of the digital economy, personnel professional competencies are becoming increasingly important. Previously, little attention was paid to people's behaviour in the company. However, today in modern organisations, competencies are essential in personnel management policy and practice.

The relevance of the topic is that the process of company personnel management and the process of forming professional personnel competencies are constantly acting factors in obtaining competitive advantages and effective performance of any organisation in general, and globalisation and the introduction of digital technology strengthen this process.
The research aimed to study the process of creating new professional competencies of personnel in a digital economy.

This topic has been studied in the works of Russian authors such as Aleksenko V.V. [1], Ilyashenko L.K. [2], Timirgaleeva R.R. [3] and others. Their studies consider the need to form competencies and new challenges of the digital economy. Still, the problem is the complexity of creating and developing new digital competencies of personnel who carry out their work activities according to old patterns. 


\section{DEVELOPMENT OF INFORMATION AND COMMUNICATION TECHNOLOGIES IN KHMAO-YUGRA}

To date, the most comprehensive digital development index is the World Digital Competitiveness Rankings by the IMD Business School in Lausanne. The ranking is reported annually in The IMD World Competitiveness Yearbook [4].

The digital competitiveness ranking aims to assess the extent to which a country uses digital technologies to effect changes in government, business models, and society.

In 2018 the U.S. ranked first in the IMD WDCR. They are followed by Singapore, Sweden, Denmark, and Switzerland. Russia ranked 40th that year, ahead of Italy and Saudi Arabia. Russia ranked reasonably high in the knowledge assessment (24th), maintaining the previous year's level. Russia ranked lower in two other categories. It rose by one position in technology development and took 43rd place. In the futurereadiness, Russia ranked $51 \mathrm{st}$.

The U.S., Singapore, Switzerland, and Denmark were also recognised as leaders in the 2019 rankings. Russia ranked 38th that year.

As of 2020, the leaders remained unchanged, while Russia dropped 5 positions and ranked 43rd in the overall ranking. Russia held the 26 th position in the knowledge ranking compared to the 22nd one in 2019. There was also some change in the country's ranking in technology: from 43rd place (2019) to 47th place (2020). In the future readiness ranking, the country dropped 11 positions.

To understand better the situation, it is worth paying attention to the Russian Federation Subjects' ranking, presented by the Ministry of Communications in 2020, according to which Yugra scored 28 points on the Business Digitalization Index, as a result of the use of cloud services, electronic trading, and the RFID technology, which is above average.

Information and communication technologies in the Autonomous Area-Yugra have been implemented for more than two decades, and the process is mainly based on the program-target method. As a result, the digital economy's organisational structure and legal framework are successfully functioning.

Recent studies carried out by the Institute for Statistical Studies and Economics of Knowledge of National Research University Higher School of Economics: "Digital Economy Indicators: 2020" state, the area, has stable and accessible information and telecommunication infrastructure, providing high-speed data transmission [5]. This has made Yugra a top-placed region in the information society ranking development rankings for a long time.

Digitalisation requires increasing investments in digital technologies and radical modernisation of almost all economic sectors, which will ensure high growth of the capital factor's contribution to the added value.

Such fluctuations in the ranking may be due to the abrupt beginning of the pandemic and the sudden change in business conditions, and the country's unreadiness to external threats.

The theoretical threat of the external environment became real and began to have a direct impact on the activities of both the general public and organisations, as well as countries and the world as a whole.

In the spring of 2020, Russia successfully shifted many businesses to remote work. The need to comply with the lockdown forced employers to transfer their staff to remote work urgently.

Experts estimate, by the end of April, the number of remote workers in Russia increased eightfold [6]. According to Gartner's analytical company, about 1/3 of all organisations refused to keep permanent employees and hired part-time employees (freelancers, IT consultants, etc.) [7].

According to the PwC survey [8], the majority of managers believe that the changes caused by the pandemic, resulting in the transition to remote work (78\%), the acceleration of automation $(76 \%)$ and office employees reduction $(61 \%)$, are here to stay. Overall, $61 \%$ say their business model will be more digital in the future, a change that has only accelerated due to the pandemic.

Respondents also believe that the pandemic has raised the importance of the personnel issue. Employee support measures during that period included health and safety $(92 \%)$, well-being $(61 \%)$, and financial support (24\%). $42 \%$ of survey participants contributed to community organisations, and nearly a third (32\%) reduced their emolument. CEOs who succeeded in retaining their staff as much as possible (36\%) and taking steps to protect employee health and safety $(92 \%)$ believe it will positively impact their organisation's long-term reputation.

Digitalisation will be a top priority for $41 \%$ of the CEOs of the world's largest companies in the long term.

Continuous changes in the current economic situation in Russia require a qualitative transformation of the nature and content of labour, increasing social and professional mobility and competitive skills of specialists in their professional practice. It makes the level and number of personnel qualification requirements grow, and the demand for highly qualified specialists possessing new knowledge and skills 
increases. The social structures and relationships continue to evolve and are often based on modern digital technologies, resulting in an evergrowing flow of data [9].

\section{APPROACHES TO BUILDING DIGITAL SKILLS}

Personnel competency becomes one of the central concepts. Competency is an integral characteristic, including knowledge, abilities and skills to perform functional duties professionally [10].

Researchers classify competencies into three main groups: hard skills, soft skills, and digital skills, despite the differences in interpretations and approaches.

Hard skills imply a set of professional skills and abilities related to technique-oriented activities. They include, for example, knowledge of technologies and their practical use, analytical and projecting skills, accounting, knowledge of computer programs and foreign languages.

This category of skills is simple to observe and easy to determine due to the objectivity of manifestation, clear expression and criteria, unambiguity and validity of an evaluation. In terms of employment, hard skills are fundamental and are indicated in job descriptions.

Soft skills are competencies that are difficult to demonstrate, test and assess in any way. These are social and psychological skills related to communication for effective interaction with colleagues, clients and partners. These skills help people find optimal solutions in a wide range of tasks that are not described either in step-by-step or job instructions.

The types mentioned above of competencies $n$ have obvious distinctions (table 1), but every business needs this or that competency depending on its functioning in the market.

Applying soft skills means using different patterns of behavior in the workplace day by day, understanding corporative and personal interests, and prioritising and making choices. The higher people go up the career ladder, the more significant the role of social skills in their life is. Therefore most of the workshops and vocational courses are focused on mastering soft skills. However, we should not forget that hard and soft skills are inseparable in professional training.

It is important to note that more than a third of the skills highlighted as a priority in 2020 was not considered that important back in 2015. The reason for this reorientation is the speed of technology development.

Among the in-demand professions are psychologists and coaches, sales managers and teachers. Valuable skills include:

1) social media communication;

2) mentoring skills;

3) the ability to retain clients [11].

Today, the pace of digitalisation exceeds the development of skills and abilities to apply digital tools by most people. Therefore, the issue of digital literacy of the population, especially in the professional environment, becomes crucial. The EU has recognised digital literacy as one of the eight critical competencies for high-quality life and performance in the modern world.

Consequently, a new category of competencies -

Table 1. Hard skills vs. soft skills

\begin{tabular}{|l|l|l|}
\hline \multicolumn{1}{|c|}{ Comparison criterion } & \multicolumn{1}{|c|}{ Hard skills } & \multicolumn{1}{c|}{ Soft skills } \\
\hline Condition of skill development & $\begin{array}{l}\text { For proficiency, logic and intelligence are } \\
\text { important, that are measured by the IQ } \\
\text { level }\end{array}$ & $\begin{array}{l}\text { A high emotional intelligence } \\
\text { coefficient is important }\end{array}$ \\
\hline Manifestation and assessability & $\begin{array}{l}\text { The possession and level of hard skills are } \\
\text { checked by examinations and } \\
\text { assessments }\end{array}$ & $\begin{array}{l}\text { The manifestation of soft skills is } \\
\text { difficult to track, measure or } \\
\text { show. There are various costly } \\
\text { personal testing procedures }\end{array}$ \\
\hline Adaptability & $\begin{array}{l}\text { Virtually unchanging, no matter what the } \\
\text { environment a person is in }\end{array}$ & $\begin{array}{l}\text { Acquired by analysing and memorising } \\
\text { available materials (lectures, books, audio } \\
\text { and video materials, personal instruction) }\end{array}$ \\
\hline Development specifics & $\begin{array}{l}\text { Skill development is based on } \\
\text { personal experience }\end{array}$ \\
\hline
\end{tabular}

Source: «Compiled by the authors» 
digital skills - emerges. Digital skills are understood as well-established, automated patterns of behaviour based on knowledge and skills to use digital devices, communication applications, and networks to access and manage information.

To assist citizens in mastering the critical competencies of the digital economy, the federal project "Human Resources for the Digital Economy" of the Russian national program "Digital Economy of the Russian Federation" has been developed and implemented. This project aims to prepare highly qualified personnel for the digital economy. Achieving the aim demands:

- ensuring accessibility of supplementary education for the population to obtain new digital competencies demanded in the labour market;

- covering the labour market demand for specialists in the IT and information security field;

- providing educational organisations of primary, basic general, secondary general and vocational education with online services [12].

The program enables to increase the number of IT specialists, which will change the requirements for job candidates. The level of digital skills will determine a person's career success and employment prospects.

The analysis of the Internet job search resources (HH.ru, Avito.ru, nizhnevartovsk.ya-ob.ru) showed that the job vacancies placed there require Microsoft Office, 1C, CorelDRAW skills, programming languages mastery, etc. Another feature of the modern labour market is that employers hunt for employees ready to:

- combine related positions;

- approach problem-solving creatively;

- go beyond their duties [12].

Competence development of human resources is becoming increasingly relevant in the latest socioeconomic context. The number of jobs requiring a basic understanding of information and communication technologies and digital technologies is rapidly growing, so the ability to use these technologies is becoming a fundamental requirement for an employee [3].

The consulting company ATKearney estimates that the demand for talent in digital technology and analytics will grow by $33 \%$ in the next five years [13].

The analysis of changes in the external and internal environment associated with the transition to the digital economy and the formation of a new technological mode shows there is a need for radical transformations of management systems in business and transformations in professional training.
The changes should meet the criterion of adaptability to the global market competition and fit the new requirements of the labour market, the business needs, state and public structures.

Eventually, it is vital to building a framework, a model of professional competencies for a region's digital economy.

\section{DEVELOPMENT OF A REGIONAL MODEL OF PROFESSIONAL COMPETENCIES FOR THE DIGITAL ECONOMY}

The competency model is a complete set of characteristics that allow people to perform the labour functions corresponding to their position.

The process of building a professional competencies model while transferring to the digital economy is an essential condition for maintaining the current efficiency and increasing competitiveness of any organisation.

After reviewing and analysing several professional competencies models and further verifying the information in terms of digitalisation, we can conclude that from the perspective of the possibility to apply universal solutions, there can be distinguished three consolidated groups of personnel competencies and skills in the digital economy:

- digital skills;

- thinking and behaviour patterns to ensure success in the digital economy, including interpersonal and intercultural communication skills;

- job-related skills specific to a particular industry.

Also, the current stage of economic development creates the need for the development of a wide range of professional competencies and prioritises the development of digital skills, which nowadays are becoming fundamental for the entire working-age population. And building a professional competencies model is a necessary functional element in achieving the goal of maintaining current efficiency and increasing competitiveness.

In addition, the analysis reveals several limitations in the existing models:

1. The distinctive features of the digitalisation process in the Russian economy are not taken into account.

2. Skills are not ranked by degree of importance or level of complexity.

3. There is no clear hierarchical or priority order of skill categories.

4. The role of digital skills is given little attention. 
Considering the needs of the professional environment, economy and society as a whole, the present study helped develop a model of professional competencies for the digital economy.

The transition to the new model of development should be accompanied by an increase in the economic and social efficiency of organisational structures and cooperative networking that people and organisations form in the course of labour and research activities.

The developed model is represented by the diagram, which contains several consolidated competencies arranged in hierarchical order with their subsequent detailing. The highlighted groups correspond to the international tendencies of skills classification, and the hierarchical arrangement of elements reflects the logic of necessary competencies formation and their interdependence.

The arrangement of elements in the model is connected with the need to master a specific category of skills in the digital environment (Figure 1).

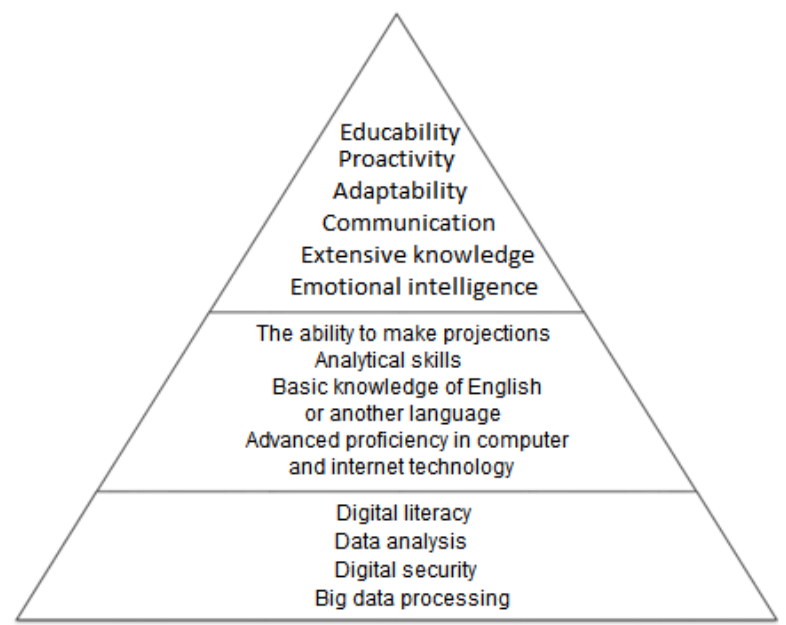

Figure 1 Conceptual model of competencies in the digital economy of Khanty-Mansi Autonomous AreaYugra.

The bottom level contains digital competencies, which are the basis and catalyst in transitioning to a new technological mode. They create the foundation for the digital thinking development of the entire population, which is the country's intellectual capital and society as a whole.

Without developing digital skills, it is impossible to compete in the global market and increase the level of implementation of digital technology; otherwise, economic and social development will be hampered. These factors determine the position of the digital skills category on the first level in the model of professional competencies.
Complex competencies represent the second level. Since technical skills are still the main criterion to employ the majority of the able-bodied population due to the specifics of job duties, low-skilled jobs, and also the simplicity of skill assessment and confirmation, this category of competencies is at the next level of the model. In addition, hard skills are the basis for the subsequent development of cognitive competencies.

At the top of the pyramid are soft skills. Without mastering this category of skills, it is impossible to perform effectively in a professional environment and everyday life. However, soft skills development does not stop at mastering a new skill or performing a specific task. This category of competencies is at the top of the hierarchy, as the need for its development follows all the lower-ranking elements.

The implementation of the model within the organisation should be carried out by the personnel management department, and the control over the implementation and assessment of the level of competencies formation - both by the personnel administration service and line managers.

To make the model convenient for practical purposes, it is also necessary to make some competencies descriptions. Firstly, it is essential to assess the candidate when selecting personnel, but such a system also helps understand the existing employees' competencies and identify them. The information about the competency level will be helpful when developing the personnel training system and making decisions concerning the use of human resources. The system of behavioural indicators was chosen as a methodology to assess the level of competencies.

\section{FORMATION OF A SET OF BEHAVIORAL INDICATORS OF DIGITAL COMPETENCIES}

It is important to note that the list of indicators may vary depending on the specifics of the organisation and the specific job position. Thus, the level of digital competencies in the IT sector will be evaluated at a more advanced level due to the need for understanding the fundamental processes and the speed of changes in the industry as a whole. It is also worth drawing attention to the lack of behavioural indicators of hard skills because they are easily observable and are often documented. In general, the system of behavioural indicators is easy to use and can be used by a large number of specialists, and not only by single-functioned specialists. Let's look at the behavioural indicators that could be detected in a job candidate or existing employee (Table 2). 
Table 2. Behavioural indicators of digital competencies

\begin{tabular}{|l|l|}
\hline \multicolumn{1}{|c|}{ Skills } & \multicolumn{1}{c|}{ Behavioural indicators } \\
\hline \multirow{3}{*}{ Digital literacy } & $\begin{array}{l}\text { Understands the basics of the Internet. } \\
\text { Can use the web environment and modern software (cloud services, learning } \\
\text { platforms, online services for creating infographics, resumes). } \\
\text { Is willing to work with new technologies. }\end{array}$ \\
\hline \multirow{3}{*}{ Data analysis } & $\begin{array}{l}\text { Can analyse information and build logical causal relationship. } \\
\text { Can analyse, organise, and summarise data. } \\
\text { Can identify and evaluate the influence of several factors on a problem. }\end{array}$ \\
\hline \multirow{3}{*}{ Bigital security } & $\begin{array}{l}\text { Understands the basic principles of information protection. } \\
\text { Knows methods of protecting information and personal data. } \\
\text { Able to ensure the integrity and confidentiality of information. }\end{array}$ \\
\hline & $\begin{array}{l}\text { Understands the demand for information. } \\
\text { Knows the terminology of the information field. } \\
\text { Knows the basics of information legislation and the rules of legal information usage. }\end{array}$ \\
& $\begin{array}{l}\text { Understands basic algorithms of information search. } \\
\text { Can perceive, process, and use a large amount of information and data. }\end{array}$ \\
\hline
\end{tabular}

Source: «Compiled by the authors»

Each block of digital competencies, if necessary, can be divided into primary and advanced levels of proficiency. The basic level of competency includes the amount of knowledge, skills, and abilities that are in demand today and not only in the professional environment. The advanced level includes specialised skills that are specific to the activities of a particular organisation or field. It should also be noted that behavioural indicators of soft skills require some specialisation or basic understanding of personality psychology (Table 3).
It is essential to keep in mind that the structure is short-term and must be subject to revision since one of the features of digital competency is its short life cycle, continuous outpacing development, and the tendency to anticipate changes in digital technology. There is no exhaustive list of qualities that will ensure a company's competitiveness. Organisations want their employees to have qualities that will allow them to continually learn and change their behaviour in a rapidly changing world.

Many researchers now discuss the importance and priority of one category of skills over the other.

Table 3. Behavioural indicators of soft skills

\begin{tabular}{|l|l|}
\hline \multicolumn{1}{|c|}{ Skills } & \multicolumn{1}{|c|}{ Indicators } \\
\hline Educability & $\begin{array}{l}\text { Have taken or are currently participating in courses, or trainings on a free subject. } \\
\text { Aware of their weak sides, gaps in knowledge and striving to fill them. } \\
\text { Positive reaction to the forthcoming training. } \\
\\
\text { Anderstanding of the role of training in personal development. }\end{array}$ \\
\hline Communication skills & Positive reaction to changes. \\
& Fast psychological adaptation. \\
& Desire to understand and explore new conditions. \\
& Adapting fast to a change of mood or topic of conversation. \\
\hline Proactivity & Not nervous, clearly express their ideas in a conversation. \\
& Interesting to talk to. \\
& Do not deviate from the main topic of the presentation. \\
& Fluent, comprehensible and moderately loud speech. \\
\hline Extensive knowledge & Use the opportunity to initiate any necessary and useful changes. \\
& Ask questions to understand the problem. \\
& Take the initiative to find new solutions that may be beneficial. \\
& Find opportunities outside their area of responsibility that may be helpful. \\
\hline Emotional intelligence and empathy & Show deep and varied knowledge when speaking. \\
& Quickly find arguments to support a point of view. \\
& Use appropriate language tools. \\
\hline & Can understand the emotional state of another person. \\
& Have a high degree of self-confidence. \\
& Willing to work not only for money, but also for other, non-material stimuli. \\
\hline
\end{tabular}

Source: «Compiled by the authors» 
Thus, the research conducted by Stanford Research Institute and the Carnegie Mellon Foundation among CEOs of Fortune 500 companies correlates with the results of a Harvard University study. Its results show that sustainable CEO success is determined $75 \%$ by their soft skills and only $25 \%$ by their hard skills [14]. This emphasises the importance of soft skills in professional personnel development for organisations.

Several other studies support this trend.

For example, the World Economic Forum analysts made an estimation in which they outlined ten key competencies which are likely to be in demand in 2020 . The top competencies include the following: complex problem solving, critical thinking, creativity, people management, communication skills, emotional intelligence, and ability to analyse and make decisions, customer-oriented approach, negotiation skills, and flexible way of thinking. It can be seen that all of these skills are soft skills.

Currently, various government agencies, consulting companies and researchers have developed different digital skills models, which in many ways complement each other. These companies are DigCompEdu 2018: The European Framework for the Digital Competence of Educators, EU DigComp 2.1. The Digital Competence Framework for Citizens [1], BCG Target Competencies Model 2025 [13], Skolkovo HR Club model [15], and New Foundational Skills of the Digital Economy by the Burning Glass company [2].

\section{CONCLUSION}

The following conclusions and suggestions were made as a result of the study. The main factor of the digitalisation process is the increase in the professional competencies level, which is based on strengthening the role of human capital.

The trends analysis in the field of professional competencies allows us to determine the most promising development directions. Thus, the soft skills category still does not lose its relevance in the employees' professional activity, and hard skills become the least important and are required in limited work activities. The most promising category of skills for today and in the long-term consideration is digital skills.

Digital skills allow you to use modern technology, acquire knowledge, skills and abilities in many other areas as efficiently as possible, and create and share digital content, communicate and solve problems for effective and creative self-realisation in learning, work and social activities in general. As a result of this research, a regional competencies model has been formed, which meets the requirements of the new socioeconomic conditions and digitalisation tendencies.

\section{REFERENCES}

[1] V.V. Aleksenko, Specific features of the modern labour market precarisation. Informacionnoe obespechenie nauki kak dvigatel' progressa. [Information support for science as a force for progress], 2020, pp. 174-175 (in Russian).

[2] L.K. Ilyashenko, Relation of the concepts of "readiness" and "competence" to the professional activity of a future specialist. Global'ny'j nauchny'j potencial [Global scientific potential], Saint Petersburg, TMBprint Publ. 7(64) (2016) 9-11 (in Russian).

[3] R.R. Timirgaleeva, I.Iu. Grishin, Digital transformation of the regional economic complex. Nauchno-metodicheskii ehlektronnyi zhurnal Kontsept [Scientific methodological e-journal 'Concept'] 12 (2018) 165-172.

[4] The New Foundational Skills of the Digital Economy. Developing the Professionals of the Future. URL: https://www.burningglass.com/wpontent/uploads/New_Foundational_S kills.pdf

[5] The Boston Consulting Group, Russia 2025: From Personnel to Talent URL: http://d-russia.ru/wpcontent/uploads/2017/11/Skills (Accessed 20.04.2021).

[6] Tsifrovaya gramotnost' i udalennaya rabota $\mathrm{v}$ usloviyakh pandemii. Sovmestnyi analiticheskii doklad VTSIOM i Social Business Group [Digital Literacy and Remote Work in the Pandemic, A Collaborative Analytical Report by Russian Public Opinion Research Center and Social Business Group], Moscow, 2020.

[7] V.S. Katkalo, D.L. Volkova, Korporativnyi universitet Sberbanka - "Korporativnoe obuchenie dlya tsifrovogo mira" [Sberbank Corporate University - Corporate Training for the Digital World], Vol. 2, 2018.

[8] G.I. Abdrakhmanova, K.O. Vishnevskii, L.M. Gokhberg, O.V. Demidkina, A.V. Demianova, Iu.Ia. Dranev, G.G. Kovaleva, M.N. Kotsemir, I.A. Kuznetsova, I.I. Kuchin, I.S. Lola, O.K. Ozerova, G.V. Ostapkovich, T.V. Ratai, Z.A. Ryzhikova, E.A. Streltsova, A.B. Suslov, Iu.V. Turovets, K.E. Utiatina, S.Iu. Fridlianova, K.S. Fursov, N.B. Shugal. Digital Economy Indicators: 2020. Nats. issled. un-t «Vysshaia shkola ekonomiki». - M.: NIU VShE [National Research University Higher School of Economics, MOSCOW: HIGHER SCHOOL OF ECONOMICS], 2020, 360 p. 
[9] PwC, CEO Panel Survey, How business can emerge stronger, 2020.

[10] Skolkovo HR Club, New reality: assumptions and facts URL: http://trends.skolkovo.ru/2016/09/hrklub-skolkovo-novayarealnost-predpolozheniya-ifaktyi/

[11] P.E. Zvyaginceva, A.Yu. Chesnokova, Challenges of the Digital Economy: Prospects and Priorities. XXI Vserossijskaya studencheskaya nauchnoprakticheskaya konferenciya Nizhnevartovskogogosudarstvennogo universiteta, [XXI All-Russian Student Scientific and Practical Conference of Nizhnevartovsk State University], 2019, pp. 178181 (in Russian).

[12] What skills employers are after in 2021. URL: https://skillbox.ru/media/business/za kakimi navy kami_rabotodateli_okhotyatsya_v_2021_godu/ (Accessed 20.09.2021).

[13] Human Resources for the Digital Economy. URL: https://digital.gov.ru/ru/activity/directions/866/\#sec tion-description (Accessed 20.09.2021).

[14] The IMD World Competitiveness Ranking, 20062021.

[15] DigComp 2.1. The Digital Competence Framework for Citizens. With eight proficiency levels and examples of use URL: http://publications.jrc.ec.europa.eu/repository/bitstr eam/JRC106281/webdigcomp2.1pdf_(online).pdf 